UDC: 338.578

DOI 10.35433/ISSN2410-3748-2020-1(26)-2

JEL Classification: I15, O23, F01

Olena Kalinichenko

Ph.D., Senior Lecturer

Department of Economics, Management and Marketing

ORCID 0000-0002-5213-1646

Iryna Poita

Ph.D., Senior Lecturer

Department of Economics, Management and Marketing

Zhytomyr Ivan Franko State University

Ukraine

ORCID 0000-0003-2137-3706

\title{
THE IMPACT OF EPIDEMIES ON THE ECONOMY OF THE WORLD
}

The article is devoted to the analysis of patterns and stable trends of the impact of world epidemics on world economy. The relevance of the study of the impact of the pandemic on the economy, as well as the mechanisms of its regulation and stabilization are substantiated. The article explores modern approaches to the impact of epidemics and pandemics on the economies of the world and Ukraine in particular, highlights some of the common aspects that have received greater attention. These pandemics have been shown to be cyclical with recurrence. The epidemic scale and its impact on the world economy are presented, leading to the breaking of economic chains and braking for several months or even one year of economic and social development. The peculiarities of functioning and the main tendencies of changes in the world economy are analyzed. The main features of the current stage of economic development of Ukraine and its impact on pandemics are identified. It is investigated which sectors of the economy undergo the first blow and identify a chain of negative economic effects through the internal and external production and commercial chains, which they were part of. The long-term effects of the impact of the crisis on the Ukrainian economy are considered, a standard set is typical in the crisis period is given. In particular, the economic losses and losses of GDP from pandemics are analyzed. The content

of the main factors influencing the economy of Ukraine during the crisis period and the proposed measures of the authorities to improve the current economic situation are revealed. On the basis of the conducted research, an anti-epidemic package of actions for the economy of the country in the domestic and foreign markets was presented. It also identified measures that should somewhat alleviate the burden on business and further stabilize the economic

(C) Kalinichenko Olena, Poita Iryna 
fluctuations caused by the pandemic. Such research is very relevant and important for a thorough understanding of the mechanism for the spread of relevant economic shocks.

Keywords: pandemic, epidemic, coronavirus, economy, globalization, power, virology

\section{ВПЛИВ ЕПІДЕМІЙ НА ЕКОНОМІКУ КРАЇН СВІТУ}

Статтю присвячено проведенню аналізу закономірностей та сталих тенденцій впливу світових епідемій на світову економіку. Обгрунтовано актуальність дослідження впливу пандемії на економіку, а також механізмів ії регулювання та стабілізації. В статті досліджено сучасні підходи до впливу епідемій та пандемій на економіку країн світу та Украӥни зокрема, виділено деякі загальні аспекти, на яких

більшою мірою акцентувалася увага. Показано, шо иі пандемії носять циклічний характер з періодом повторення. Наведено дані масштабу епідемій та їх вплив на світову економіку, приводячи до розриву економічних ланцюгів і гальмування на кілька місячів або навіть до одного року розвитку економіки і суспільства. Проаналізовано особливості функціонування та основні тендениії змін в світовій економічі. Визначено основні ознаки, притаманні для сучасного етапу розвитку економіки Украйни та вплив на неї пандемій. Досліджено, які саме сектори економіки зазнають першого удару та

виявлено ланиюг негативних економічних ефектів через внутрішні та зовнішні виробничо-комериійні ланцฺюги, до складу яких вони входили. Розглянуто довгострокові ефекти впливу кризи на украӥнську економіку, наведено стандартний набір, властивий саме у кризовому періоду. Зокрема, проаналізовано економічні збитки та втрати ВВП від пандемій. Розкрито зміст основних чинників, які впливають на економіку України в період кризи та запропоновані заходи влади для поліпшення економічної ситуації, щуо склалася. На основі проведеного дослідження було наведено протиепідемічний пакет дій для економіки країни на внутрішньому та зовнішньому ринках.. А також, визначено заходи які повинні дещсо послабити навантаження на бізнес та в подальшому стабілізувати економічні коливання заподіяні пандемією. Таке дослідження є дуже актуальним та важливим для детального розуміння механізму поширення відповідних економічних шоків.

Ключові слова: пандемія, епідемія, коронавірус, економіка, глобалізація, влада, вірусологія

Problem statement. There is a theory that every 100 years a pandemic erupts on the planet. You can say that this is a coincidence, but the chronology is alarming. In 1720 it was a plague, in 1820 it was cholera, and in 1918 it was Spanish flu. Many researchers say that the current coronavirus epidemic is reminiscent of the events of previous centuries. The outbreak of the COVID - 19 epidemic has become, without exaggeration, another challenge for humanity of a global nature. On the one hand, it is about the ability to quickly and effectively identify the nature of another pathogen and to develop appropriate techniques and pharmaceuticals for treatment. On the other hand, any epidemic, not to 
mention a pandemic, has very specific short-, medium- and long-term economic consequences.

Ukraine, like the whole world, is facing a turbulent period in economic development. The COVID-19 coronavirus epidemic was a kind of "amplifier" of the negative trends that shook the world markets in early March. Suppose that even if Ukraine were ready for the next round of the global financial crisis, the weakness of the domestic economy would still make itself known. All known "diseases" of the Ukrainian economy can already be called chronic, and they have not disappeared for more than 20 years now.

And if we add to this a few negative factors - the Donbas war, a change of government and uncertainty with the implementation of further economic reforms - we have reason to believe that the Ukrainian economy can expect another large-scale collapse.

Analysis of recent research and publications. Certainly today the issue of the impact of pandemics and the economy of the world is quite relevant. However, unfortunately, the postulates are considered quite superficially in the scientific literature, in terms of virology, epidemiology and philosophy. There are only selected articles on the impact of pandemics on economic and socioeconomic development. First of all, there was a need to refer to works that seek to capture the phenomenon of the pandemic as such. The works of the classics Avicenna, Hippocrates began. A significant contribution was made by those who dealt with the pandemic in the second half of the nineteenth century. - first half of the twentieth century: G. Vogralik, M. Galanin, D. Zabolotny, K. Seydlitz, S. Mashkovsky, E. Pavlovsky, etc. Among the modern researchers I would like to note the following: R. Anderson, R. Mei, O. Andriychuk, G. Artyunin, O. Baroyan, V. Belyakova, T. Semenenko, M. Shrag, G. Bilich, K. Vasiliev, L. Gromashevsky, S. Deshevoy, B. Wild, E. Dobroshtan, I. Litkin, V. Pokrovsky, O. Rechkin, V. Saveliev, M. Supotnitsky, B. Cherkasky, O. Chizhevsky, S. Shakh, etc. Among the western researchers of the pandemic 
phenomenon, I note L. L. Little, W. J. Mahi Bryan, L. Muta, A. R. Omran, R. Preston, D. Quammen, S. Scott, N. Wolfe, and others.

The purpose of the article is to show the impact of pandemics on the economy of the world and countries, because every crisis is a time not only for testing, but also for new opportunities. The fact that the authorities now have a clear understanding of the challenges and an opportunity to consolidate their efforts adds to the optimism. Obviously, there is a lack of experience and managerial skills in times of crisis, but in almost all circumstances, almost all the governments of the countries of the world and Ukraine in particular have been exposed.

Presenting main material. The threat of a new epidemic loomed above the world - the coronavirus, which began its movement in China, seized more and more states, taking away the lives of their inhabitants. During 01/04/2020 the number of patients increased by about 75 thousand. Which is one of the biggest indicators since the start of the pandemic. In the course of a day, about 4,5 thousand people died on the planet of COVID-19, which is the world record of daily mortality from coronavirus [1].

Outbreaks have always plagued humanity. The data presented (Table 1) indicate that, despite all our tremendous successes in various fields, epidemics are a real global problem, because in a rapidly globalizing world, economic, medical and other problems of individual countries and regions can quickly emerge. problems of the world community.

According to World Bank experts, pandemics today can be a real shock to the world economy: a serious pandemic can cause economic losses at almost 5\% of world GDP, or more than \$ 3 trillion, while losses from a "weak" influenza pandemic (such as the H1N1 virus in 2009) can cost about $0.5 \%$ of world GDP [6].

By the way, for the sake of completeness, epidemics affecting animals and plants should be mentioned. According to the experience of previous epidemics, 
the countries with the most epidemic outbreaks suffer the greatest economic losses, but the losses have a very clear sectoral link.

Table 1

Scale of Global Epidemics

\begin{tabular}{|c|c|c|c|c|}
\hline $\begin{array}{l}\text { Epidemic / } \\
\text { Pandemic }\end{array}$ & Year & $\begin{array}{c}\text { Approximate } \\
\text { number of infected }\end{array}$ & $\begin{array}{l}\text { Estimated deaths, in } \\
\text { the world overall }\end{array}$ & $\begin{array}{l}\text { Mortality } \\
\text { rate, \% of } \\
\text { infected }\end{array}$ \\
\hline $\begin{array}{c}\text { Spanish flu } \\
\text { (Spanish) }\end{array}$ & 1918-1919 & 500 million & 50-100 million & 2-3 \\
\hline $\begin{array}{c}\text { Asian } \\
\text { influenza }\end{array}$ & $1956-1958$ & Estimates & $1-4000000$ & na \\
\hline $\begin{array}{l}\text { Hong Kong } \\
\text { flu }\end{array}$ & 1968-1969 & Assessment no & 1.4 million & data available \\
\hline SARS & $2003-2003$ & 8098 & 774 & 9.6 \\
\hline Swine flu & $2009-2010$ & 10-200 million & $\begin{array}{l}\text { from } 18,500 \text { laboratory- } \\
\text { confirmed cases, } \\
\text { according to WHO) to } \\
\text { 203,000 (estimated } \\
\text { Lancet) }\end{array}$ & \\
\hline MERS & $\begin{array}{l}\text { From } 2012 \\
\text { to the } \\
\text { present }\end{array}$ & $\begin{array}{c}1917 \text { laboratory } \\
\text { confirmed cases in } \\
17 \mathrm{cr} \text { ainah (WHO } \\
\text { data) }\end{array}$ & 6677 & 36 \\
\hline Ebola & 2013-2016 & 28616 & 11310 & 39.50 \\
\hline $\begin{array}{l}\text { Seasonal } \\
\text { influenza }\end{array}$ & annually & $\begin{array}{l}340 \text { million - } 1 \\
\text { billion }\end{array}$ & $\begin{array}{l}250000-500000 \\
\text { annually }\end{array}$ & $\begin{array}{c}\text { Each type of } \\
\text { flu has its own } \\
\text { coefficient }\end{array}$ \\
\hline
\end{tabular}

Source: WHO: European Center for Disease Prevention and Control; The Economist Intelligence Unit

Therefore, the combined economic impact of these two types of epidemics is quite tangible globally.

Today, almost all experts agree that the epidemic will have a negative impact on the world economy. However, most of the calculations are based on the assumption that the epidemic will be overcome in the first quarter of 2020 , and therefore the impact will be noticeable, but short-term.

The fact that the Ukrainian economy will slow down the growth rate is an obvious fact. The world economic growth rates will decline substantially, and with them, of course, will slow down its growth and the GDP of Ukraine [2]. 
However, economists have warned of slowing global GDP growth even before the start of the pandemic coronavirus. But for Ukraine, the forecasts were even better than the world. Thus, the World Bank improved its forecast for Ukraine's GDP growth in 2019 from $2.7 \%$ to $3.6 \%$. Other factual figures and forecasts are worth noting. In 2019, GDP growth slowed slightly compared to 2018 - from $3.4 \%$ to $3.3 \%$.

At the beginning of the current year, the National Bank pointed out the gradual growth of the domestic economy to $3.5 \%$ in 2020 and $4 \%$ in 2021-2022 [7].

However, it was March that the Ministry of Economic Development, Trade and Agriculture recorded a slowdown in GDP growth for the first time since 2016. Probably not the best results will be in April and May. However, it is during these months that the state receives taxes for the first quarter of the current year and it is possible to predict the prospects for further economic development, given these indicators.

In addition to slowing GDP growth, a standard set of crisis-specific periods is expected in Ukraine: a fall in industrial output, a devaluation of the hryvnia due to exporters' lack of foreign exchange earnings, and an increase in government debt.

The outbreak of the coronavirus epidemic has affected the economy of China, and with it a chain reaction will affect the whole world. It is primarily about the trade and production of goods and components manufactured in the PRC. The world's second-largest economy has hit a major blow, which means that an explosive wave will affect everyone without exception [4].

In Ukraine, a slowdown in the global economy can lead to a decline in business activity, which will automatically mean rising unemployment. Moreover, the "outlet" in the form of foreign currency transfers from employees may not work this year. Production downturns and contractions will accompany the entire EU economy. 
Among the long-term effects of the impact of the crisis on the Ukrainian economy at the National Bank are called a reduction in exports and a decrease in the attractiveness of government debt securities. In addition, the situation will worsen with debt. And in combination, all these factors will accurately affect the depreciation of the hryvnia. No one can predict the exact depth of the devaluation of the national currency, but the National Bank has spent about \$1 billion of accumulated reserves over the last week to keep the hryvnia from falling sharply, although the domestic currency has devalued by 1.9 hryvnias for one week [9].

Obviously, further devaluation will lead to higher prices. However, with at least a 5 -week nationwide quarantine, other risks should be addressed.

First and foremost is the loss of small and medium-sized businesses. The tourism industry, services, transportation will suffer. In addition, the government has already recorded about $20 \%$ of the planned proceeds from customs in the last two months. Reduced earnings from workers. Perhaps a wave of contractions in the real sector of the economy is expected in April and May [3].

The government is trying to at least slow down the negative effects caused by quarantine and forced economic slowdown. Thus, at an extraordinary session of Parliament, a number of decisions were made to ease the tax burden on businesses. The Verkhovna Rada exempted all entrepreneurs from the ESU for 2 months from payment, temporarily abolished penalties for late payment of the ERU, introduced a temporary moratorium on business checks until July 1, postponed payment of land and real estate tax until the end of May forced ordinary businesses are exempted from paying PIT.

In addition, the Verkhovna Rada provided for exemption from penalties for late payment on consumer loans from March 1 to April 30 this year. All these measures should somewhat alleviate the burden on the business, however, will significantly affect the overall decline in business activity and do not offset 
a significant loss of profit. This means that in the coming months, Ukrainians will have to tighten their belts significantly.

The quarantine measures due to the coronavirus epidemic will affect not only business owners, but also all citizens of Ukraine without exception. First of all, changes will occur in the work schedule and the way to make money. Many Ukrainians will try themselves as "freelancers" or simply work from home [5].

The logistics and traditional leisure of Ukrainians will change. Apparently, online entertainment services will be more popular. Demand for online trading and delivery of ready-made food and consumer goods will increase. Private carriers will definitely increase tariffs, as public transport will have significant restrictions.

It is also interesting that the current situation exposes a number of problems with logistics and communication. Thus, to the mayors of large cities, their residents may ask the question of underdeveloped cycling infrastructure, which could significantly facilitate urban travel while at the same time not carry great risks for the spread of the disease [1].

Announcing the government's plans, President Volodymyr Zelensky drew attention to the fact that it was during this difficult period of introducing quarantine measures that Parliament should not forget about reforms in such areas as labor and pension legislation. As a separate item, the President stressed the need to restore financial support from the IMF as soon as possible, which would automatically mean speeding up the history of the land market launch and resolving the situation with PrivatBank.

Obviously, while the authorities have little to say about a clear plan for dealing with the crisis in the internal financial sector. First of all, it is about state support for business entities that can go bankrupt

One way or another, quarantine and the financial crisis will be for many Ukrainians one more proof that seeking a better fortune abroad or hoping for big wages carries with it such the same risks as solving a number of problematic 
issues at home. That is why the new crisis and coronavirus can become a reference point as more and more Ukrainians focus on ordering things at home. However, as little as possible hoping for any assistance from the state [8].

Since periodic pandemics have, unfortunately, become an integral part of human life, no country in the world is immune to their direct or indirect impact. Under these conditions, countries should be economically ready to act quickly and effectively on the formula "fighting the epidemic - minimizing the negative short, medium and long term effects." Such an economic anti-epidemic package should take into account several mandatory elements.

Firstly, the costs involved in ensuring that national governments are prepared to act in the event of a pandemic. These costs can be considered as an investment in minimizing possible future problems. Allocating these funds is not a difficult political decision, as they are effectively eliminated from the economic turnover and cannot be directly used to solve certain pressing socioeconomic problems.

In fact, it is about the financial preparedness of national governments for epidemics (ie the ability to quickly and adequately fund anti-epidemic measures). By the way, in 2016, the World Bank has set up an ad hoc working group on financial preparedness for epidemics, which should come up with appropriate recommendations for national governments.

Secondly, public and private costs associated with the treatment of patients and the implementation of anti-epidemic measures. In part, these costs are covered by the reserve mentioned above. At the same time, the government should have a clear understanding and, better, a detailed mechanism for how to raise additional funds if the epidemic financial reserve is insufficient.

Thirdly, the costs associated with the negative impact of pandemics on the country's economy (loss of production, productivity, etc.). Obviously, here it is possible to speak, rather, not about direct budgetary subsidies, but about 
measures of restoration (stimulation) of economic activity in the post-epidemic period [7].

Conclusions from this study. So, it is almost impossible to predict the end of a coronavirus pandemic. The sooner scientists can invent the vaccine, the less global damage will be, but it is not so easy to do. In addition, the virus is spread throughout the world. The number of cases in the world has already exceeded 100 thousand, and according to analysts - the peak will fall in midMarch. Therefore, it is unknown how severe the financial consequences of the disease will be.

The best thing to do now is not to panic by buying essentials and tossing national currency into buying dollars. Because, at the moment, panic remains far more dangerous than the coronavirus itself.

\section{REFERENCES}

1. Sait zhurnalu «Eurosurveillance: yevropeiskyi zhurnal shchodo nahliadu za infektsiinymy zakhvoriuvanniamy, epidemiolohii, profilaktyky ta kontroliu» [Site of journal «Eurosurveillance: Europe's journal on infectious disease surveillance, epidemiology, prevention and control»]. www.eurosurveillance.org. Retrieved from: https://www.eurosurveillance.org/ [in Ukrainian].

2. (2020). Ne vmyraty chas Svitovyi rekord smertnosti, v Rosii tysiacha khvorykh za 2 dni, u Turkmenistani koronavirus zaboronyly [No time to die:World record of deaths in Russia, a thousand patients in 2 days, in Turkmenistan banned coronavirus]. www.pravda.com.ua/news/2020/04/1/7246001. Retrieved from: https://www.pravda.com.ua/news/2020/04/1/7246001/ [in Ukrainian].

3. Statystyka Yevropeiskoho tsentru profilaktyky ta kontroliu zakhvoriuvan, ahentsii Yevropeiskoho Soiuzu [Statistics from the European Center for Disease Prevention and Control, an agency of the European Union]. 
(n.d.). www.ecdc.europa.eu. Retrieved from: https: // www.ecdc.europa.eu/ [in Europe].

4. Latora, V., \& Marchiori, M. (2003). Ekonomichna povedinka maloho svitu u zvazhenykh merezhakh [Economic small-world behavior in weighted networks]. Yevropeiskyi fizychnyi zhurnal BCondensed Matter and Complex Systems - The European Physical Journal BCondensed Matter and Complex Systems, 32 (2), 249-263 [in Europe].

5. Yagudina, R.I., \& Zinchuk, I.Yu., \& Litvinenko, M. M. (2012). Analiz «vartosti zakhvoriuvannia»: vydy, metodolohiia, zvitnist [Analysis of the "cost of the disease": types, methodology, reporting]. Farmaekonomika Pharmaeconomics, 1, 4-9 [in Ukrainian].

6. Virus retsesii: shcho stanetsia vid svitovoi ekonomiky pislia pandemii [Recession virus: what will happen to the global economy after the pandemic]. mind.ualen/openmind/20209018-virus-recessii-chto-budet-s-mirovojekonomikoj-posle-pandemii. $\quad$ Retrieved from: https://mind.ua/en/openmind/20209018-virus-recessii-chto-budet-s-mirovojekonomikoj-posle-pandemii [in Ukrainian].

7. Koronavirus u chyslakh: yak zminylasia svitova ekonomika [Coronavirus in numbers: how the world economy has changed]. www.bbc.com/ukrainian/features-51994936. Retrieved from: https://www.bbc.com/ukrainian/features-51994936 [in Ukrainian].

8. Maa, A. (2014). Sorok dniv i chorna smert. Pokhodzhennia ta etymolohiia poniattia [Forty Days and the Black Death. Origin and etymology of the concept]. Karantyn ta yoho znachennia - Quarantine and its meaning, 5, 14 [in Europe].

9. Peredbachennia COVID-19: Vplyv na ekonomiku ta suspilstvo [COVID19 Foresight: Impact on Economy and Society]. wdc.org.ua/uk/covid19. Retrieved from: http://wdc.org.ua/uk/covid19.

Стаття надійшла до редакиії 24.03.2020

(C) Kalinichenko Olena, Poita Iryna 